\title{
Permissibility of Death Penalty as a Hermeneutic Dilemma ${ }^{1}$
}

\author{
MICHAt KOSCHE
}

The John Paul II Catholic University of Lublin

michal.kosche@kul.lublin.pl, ORCID: 0000-0002-1715-0510

\begin{abstract}
The notion of moral fairness regarding the application (or not) of capital punishment is stretched between two poles of opposite interpretative meanings. On the one hand, there is an imperative related to maintaining the social order which justifies, in some specific cases, the killing of an individual for the good of the community. On the other hand, there is the message of the Gospel about the holiness of each human life. Thus, in attempting to investigate the fairness of the death penalty, a certain hermeneutic tension arises around the overlapping rights and obligations pertaining to both the criminal and the society that needs to be protected against him or her. This article starts from an outlook on the death penalty that pays due regard to a 'hermeneutic charge' that encompasses both the duty to protect the common good and also the value of each individual's life. Next, the 'genuine paradox' was analysed which emerges in a situation where the right to live and the right to protect overlap. All these considerations are finally brought to bear on a question: whether the recent abolitionist interpretation of the Catechism of the Catholic Church should be classified as the continuity hermeneutic or, rather, the discontinuity hermeneutic.
\end{abstract}

Keywords: Death penalty, theological hermeneutics, philosophical hermeneutics, John Paul II, Francis, St. Thomas Aquinas

The matter of permissibility of death penalty in Christian thought was addressed repeatedly. The answers provided by theologians and philosophers regarding its fairness and permissibility varied as well. Since faith in Christ started taking on the form of a specific doctrine people became aware of the fact that the matter of moral fairness of applying capital punishment somehow collides with the message of the Gospel about sacred nature of each human life. Due to the awareness of this tension, it was necessary that an answer if found to the question, how could the permissibility of death penalty be reconciled with, for instance, the "you shall not kill" commandment?; or, how does Christ's merciful sacrifice relate to the 'harsh' justice the delivery of death penalty is linked to? Does not the truth about a man as imago Dei, or even imago Christi, guard the integrity of human life? Or maybe preserving social order

1 The project is funded by the Minister of Science and Higher Education within the program under the name "Regional Initiative of Excellence" in 2019-2022, project number: 028/RID/2018/19, the amount of funding: 11742500 PLN. 
and good does justify killing an individual for the good of the community in some specific cases after all? All these questions Christian thinkers of the past ages had to confront pertain also to our modern era. Over the last several decades, the answer of the Church to the question about the permissibility of death penalty has evolved from a relatively retentionist stance to an abolitionist one. This has given birth to another problem related to the issue of legally justified (or legally unjustified) development of the Church doctrine regarding capital punishment. Why did the great of the Church, such as St. Augustine or St, Thomas, allowed for (or even recommended at times) the use of death penalty while since the encyclical Evangelium vitae, Magisterium was clearly distancing itself from this form of penalty until it completely abolished it under the new version of the Catechism of the Catholic Church no. 2267?

It seems that in order to give satisfying answers to the above questions would require reflecting on the issue of death penalty in hermeneutic perspective. The starting point here is the outlook on death penalty with due regard to the 'hermeneutic charge' contained in the duty to protect the common good and each man's life. Then, we shall analyse the 'genuine paradox' that emerges in a situation involving co-occurrence of law and the right to live and the right to protect oneself. All the discussion shall be concluded with a question about whether the recent abolitionist interpretation of the Catechism of the Catholic Church should be classified as the continuity hermeneutic or the discontinuity hermeneutic.

\section{Between an Individual's Dignity and the Common Good}

The issue of validity and fairness of death penalty stretches between two fundamental values, namely, dignity of a human being and the good of the community. Therefore, it is a hermeneutic problem consisting in proper interpretation of the act of taking life of another person who perpetrated the most wicked crime. We could effortlessly find logions involving a significant interpretative charge of the use of capital punishment as early as in The Old Testament. In the Book of Genesis, the inspired author puts the following words into the mouth of Yahweh himself, "And for your lifeblood I will surely demand an accounting. I will demand an accounting from every animal. And from each human being, too, I will demand an accounting for the life of another human being. Whoever sheds human blood, by humans shall their blood be shed, for in the image of God has God made mankind" (9:5-6). One can find in Torah a list of crimes and offences that should be sanctioned by death. Very often, the biblical narrative ascribes such legislature to God himself. On the opposite interpretative pole there are texts about the holiness of human life stemming right from the act of creation. For the problem of death penalty, pericopes about Adam's and Eve's sin 
are also significant, as well as those about Cain and Abel. The personal guilt of the first parents has brought the biggest negative consequences for the entire human community in the history of man, and nonetheless, it was not sanctioned by God to be punishable by death. Likewise, Cain's act was not punished by Yahweh by death despite blood of just Abel crying for vengeance. Although the Creator unequivocally condemns the sin of fratricide, He neither kills Cain nor allows anyone else to kill him, giving the brother-killer a mark "so that no one who found him would kill him" (Genesis 4:15). These several biblical pericopes already make us see the Old Testament as a book where death penalty is accompanied by varying hermeneutic charge.

The situation is similar when it comes to the New Testament. As the only just, Christ gives His life for the unjust by means of the Sacrifice of the Cross, which was nothing else than death penalty performed in accordance with Jewish priests and Pilate at the time, justified by the need to protect social order and the common good. The belief of High Priest Caiaphas, that it would be the best for the people of one died for many (John 11:49) proved the greatest injustice in the history of mankind. Likewise, the death of St. Stephen was justified by the Sanhedrin with the need to protect the common good and faith.

However, the New Testament also contains texts that seem to allow for the use of death penalty under some circumstances. This is the spirit in which St. Paul's teaching expressed in the Letter to Romans is interpreted, where the Apostle of Nations states the rightful secular authority "For the one in authority in God's servant for your good. But if you do wrong, be afraid, for rulers do not bear the sword for no reason. They are God's servants, agents of wrath to bring punishment on the wrongdoer" (Romans 13:4). Furthermore, the example of Ananias's and Saphira's deaths described in the Acts of the Apostles sheds a significant light on the biblical hermeneutics of death penalty. The married couple lied and kept part of the money for land they sold to themselves. In their attempt to lie to the Apostles, according to St. Peter, they put the Holy Spirit Himself to the test. As a consequence of this deed, they both died.

It is challenging to find in the Bible, either the New or the Old Testament, an unequivocal interpretation on the moral permissibility of death penalty. One may rather talk about a certain mosaic of examples and specific situations that can serve for creating by systematic theology a certain hermeneutic horizon which would allow one to answer the question about the permissibility of capital punishment. This view is reflected in the teachings of the Fathers of the Church. Although many of them approved of the use of capital punishment as a penitentiary instrument applied by the state authorities, there were also some who considered it unfair. The most notable retentionists are, among others, Clement of Alexandria, a $2^{\text {nd }}$-century Christian apologist. Referring to a stance taken by Seneca in his work Stromata $\left(\sum \tau \rho \omega \dot{\mu} \mu \alpha \tau\right.$ in Greek), he develops a moral-theological concept of the justification of death penalty 
by comparing the right of the state to eliminate a criminal to an act done by a surgeon removing an organ that is not suitable for treatment and may put a patient's life in danger ${ }^{2}$. The most influential Christian thinkers of subsequent centuries, including the Greeks Catholics and Origen of Alexandria (Contra Celsum), or Latin rite Catholics such as Tertullian (De Spectaculis) maintained a dualism of some sort in their relation to death penalty. They believed it could be applied under some circumstances by the pagan authorities, yet Christians must not take part in imposing death sentences, as they are in conflict with the Gospel. A similar duality occurred in the teachings of Lactantius ${ }^{3}$. Following the Edict of Milan, theologians could no longer preach the mentioned duality since by the will of Constantine the Great, Christians were holding the most prominent positions in the empire. Therefore, a need arose for developing a unified stance on capital punishment ${ }^{4}$.

The thinker who succeeded in doing so was St. Augustine ${ }^{5}$. In the work The City of God (De civitate Dei) in Book One, Chapter 21, he justifies the murder of a criminal if performed by lawful state authorities driven by care for the common good. Hence, Doctor Gratiae considers such an act as not classifiable as the sin of killing. Nonetheless, Augustine does not provide an exhaustive explanation of his thesis. Although he refers to justice, he fails to justify how it would take place in such a case. Instead, the Bishop of Hippo refers to the right given by God, which allows for a very wide range of interpretations, carrying a serious risk of overinterpretation ${ }^{6}$. Augustine's theory has been commonly adopted in the area influenced by Latin civilisation. Many countries that describe themselves as Christian used death penalty referring to it without having to risk accusations of breaking the God-given right?

In the Middle Ages, Thomas Aquinas in Summa Theologiae (hereafter STh) also supported permissibility of death penalty in the case of a justified and serious threat to the common good. Aquinas justified his concept on the occasion of discussing justice in the part dedicated to murder ${ }^{8}$. Referring to the principle of assigning a part to the whole, Doctor Angelicus states, "Therefore if a man be dangerous and infectious to the community, on account of some sin, it is praiseworthy and advantageous that he be killed in order to safeguard the common good, since "a little leaven corrupteth

Clement of Alexandria, Stromateis [1.27], 148-151.

Ślipko, Kara śmierci, 33 .

As a side note it should be added that Christianisation of the empire as a socio-political fact has made a great impact on theology itself. Since then, the interpretation of faith has been subject to a strong "hermeneutic pressure" that does not stem from the Revelation but is related to secular authority. This process shall accompany the teaching of the Church to a lesser or a greater extent at least until the Second Vatican Council and its breakthrough statement about autonomy of the mundane.

5 Thompson, "The New Natural Lawyers," 182-183.

6 Augustine of Hippo, The City of God, 33.

7 Ślipko, Kara śmierci, 37-41.

8 STh II-II q. 64. 
the whole lump" (1 Cor. 5:6)"9. Hence, he supports the understanding of the issue of capital punishment that puts the good of the community above the good of an individual. However, not everyone is allowed to make a death sentence. This cannot be done by a private person but solely by state authorities ${ }^{10}$. The clergy are also not allowed to participate in proceeding this punishment due to two reasons: firstly, they are called to serve at the altar, and hence they must follow the Master who, despite suffering did not threaten to seek vengeance; secondly, due to the fact that the clergy were tasked with serving 'the New Law' that does not provide for corporal punishment and all the more so death punishment ${ }^{11}$. Therefore, in Thomas's vision the clergy are an exception to the rule of some sort with its hermeneutic meaning. Perhaps it is that here, the stance of the Church Fathers mentioned above comes into play, according to which death penalty is not compliant with the law of the Gospel, although it might be justified by the state law. Thomas expresses his claim again also when it comes to analysing murder committed to ensure necessary self-defence when he states that any murder, even a sinless one, constitutes an incongruence even it comes to a judge who justly sentenced someone to death. That is why a clergyman, even if he would kill someone in his own defence, falls into this incongruence, even if his intention was not to kill but to protect himself ${ }^{12}$. Although Aquinas's teachings regarding the permissibility of death penalty is unambiguous, it still leaves a lot in question, such as issues related with the loss of human dignity. This subject shall be analysed further in the paper where the matter of the 'genuine paradox' is discussed.

Over the subsequent centuries, the Church has repeatedly confirmed the moral permissibility of using death penalty by public authorities to protect the common good. This was done by, among others, Leon X, Pius V, Leon XIII, Pius X,' Pius XI and Pius XII ${ }^{13}$. A significant document of the Magisterium on capital punishment was established under the Apostolic constitution Fidei depositum by John Paul II in 1992 The Catechism of the Catholic Church (hereafter CCC). While the teachings of Thomas Aquinas unequivocally put the common good over the good of an individual lecture of the Catechism, despite allowing for the use of capital punishment, gives a voice also to abolitionist argumentation stemming from the dignity of a human being, which orders the authorities to use bloodless measures if they are sufficient for defending oneself against an attacker (CCC 2267). A further shift towards abolitionist interpretation may be observed in the encyclical of John Paul II Evangelium vitae of 1995. The Pope claims there that state authorities "ought not go to the extreme of executing the offender except in cases of absolute necessity: in other words, when it would not be possible otherwise to defend society. Today however, as a result of

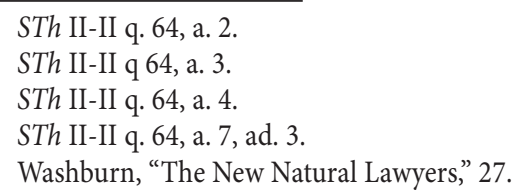


steady improvements in the organization of the penal system, such cases are very rare, if not practically non-existent" ${ }^{14}$. These teachings have been introduced to the interpretation of the Catechism in 1998.

The stance adopted by John Paul II is characterised by a specific hermeneutic tension between the arguments supporting the necessity of protecting the common good even at the price of annihilating the perpetrator and the arguments stemming from the ontology of an individual as a being bestowed with non reducible dignity both in the philosophical and theological sense. However, it ought to be noted that the stance of the Church regarding death penalty during the pontificate of the Polish pope shifted considerably towards abolitionist interpretation. This interpretative direction was also shared by Benedict XVI, although he did not decide on any significant change in the doctrine ${ }^{15}$. Pope Francis took stance against using death penalty on two occasions. In his Letter to the President of the International Commission against the Death Penalty he claimed, "today capital punishment is unacceptable, however serious the condemned's crime may have been"16, whereas in his speech to the Pontifical Council for Promoting the New Evangelization he stated, "no matter how serious the crime that has been committed, the death penalty is inadmissible because it is an attack on the inviolability and the dignity of the person"17. Still, the greatest novelty in that pontificate is the introduction of yet another change to the Catechism lecture on death penalty in 2018. By virtue of item 2267 was worded as follows,

Recourse to the death penalty on the part of legitimate authority, following a fair trial, was long considered an appropriate response to the gravity of certain crimes and an acceptable, albeit extreme, means of safeguarding the common good. Today, however, there is an increasing awareness that the dignity of the person is not lost even after the commission of very serious crimes. In addition, a new understanding has emerged of the significance of penal sanctions imposed by the state. Lastly, more effective systems of detention have been developed, which ensure the due protection of citizens but, at the same time, do not definitively deprive the guilty of the possibility of redemption. Consequently, the Church teaches, in the light of the Gospel, that 'the death penalty is inadmissible because it is an attack on the inviolability and dignity of the person', and she works with determination for its abolition worldwide ${ }^{18}$.

It is an abolitionist interpretation that unambiguously supports integrity of the dignity of a human being. On the other hand, it supports the traditional teachings about

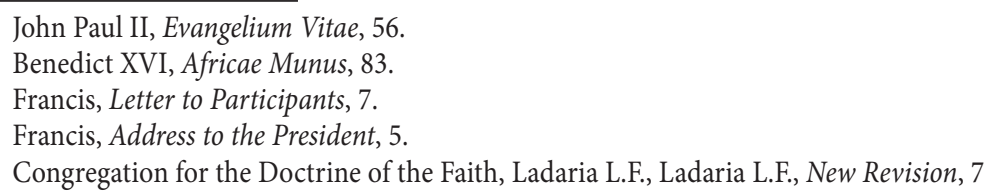


the state as the guarantor of citizens' safety, which in the modern era not only 'does not have to' but even 'cannot' be realized by taking life anymore.

\section{The 'Genuine Paradox'}

Taking a look at the issue of death penalty from a hermeneutic perspective, one can arrive at a conclusion that the attempt at morally justifying its application leads straight to a certain paradox. This paradox arises when in a specific situation fundamental rights such as the right to defence and the right to live overlap (or even conflict in a sense). When reflecting on the issue of legally justified protection, John Paul II in the encyclical Evangelium vitae wrote,

There are in fact situations in which values proposed by God's Law seem to involve a genuine paradox. This happens for example in the case of legitimate defence, in which the right to protect one's own life and the duty not to harm someone else's life are difficult to reconcile in practice. Certainly, the intrinsic value of life and the duty to love oneself no less than others are the basis of a true right to self-defence. The demanding commandment of love of neighbour, set forth in the Old Testament and confirmed by Jesus, itself presupposes love of oneself as the basis of comparison: 'You shall love your neighbour as yourself' $(\text { Mk 12:31) })^{19}$.

The right of a state to sentence a person to death is a specific case of the right to defence. It is specific due to at least two reasons. Firstly, its subject is not an individual but the state that protects citizens and, secondly, when the perpetrator is caught after perpetrating a crime, he or she does not constitute real threat anymore as in the situation of necessary defence against an aggressor, but potentially. In relation to these differences, if we put the matter of fairness of death penalty in the perspective of continuous tension between legal defence of the common good and the necessity to respect an individual's dignity (including the perpetrator) this 'genuine paradox' does not take any more such a radical form and strictness it preserves in the case of necessary defence. This is because it is not necessary that the state must punish a perpetrator with death for his or her fault or to protect citizens.

When reflecting on death penalty, John Paul II considers it in Evangelium vitae exactly a specific case of the 'genuine paradox'. On the one hand, there is human dignity and the properly understood penal justice that should correspond to human dignity and thus to God's idea about the man and society to an increasingly greater

19 John Paul II, Evangelium Vitae, 55. 
extent ${ }^{20}$. This idea is perfectly expressed in the pericope about Abel and Cain. On the one hand, as we may read in the Book of Genesis, Cain is damned by God for murdering his just Brother, while on the other hand, God remain merciful even when punishing the man, as evidenced by His mark bestowed upon the brother-killer so that he himself would not get murdered. In the optics of John Paul II, the Creator's attitude towards Cain allows us to state that "Not even a murderer loses his personal dignity, and God himself pledges to guarantee this"21.

On the other hand, in order to do what it has been founded to do, i.e. to protect social order and prevent infringement of personal and social rights, a just state is even obligated to punish a perpetrator by sentencing him or her accordingly to the weight of his or her fault. In line with classic theology, if there is no other possibility to effectively protect society, state authorities may seek to apply capital punishment. And thus, we have arrived at the opposite side of the paradox.

Being perfectly aware of the paradoxicality of the Church teachings when it comes to death penalty, John Paul II did not decide to adopt the abolitionist stance. He chose the path of incentive to refrain from the use of capital punishment arguing that at present, cases where it is absolutely necessary that death penalty be used are either very rare or non-existent ${ }^{22}$. Perhaps this stance is due to a belief that as a hermeneutic being, a man is 'condemned' to exist and act strictly in the space of a paradox where due to sin and human fault in certain situations protecting some values calls for the necessity to 'suspend' others. It is also likely that the issue of human dignity is considered by John Paul II partly similarly to Thomas Aquinas who saw adoption of punishment (including death penalty) as a possibility to redeem oneself from guilt.

Speaking of Aquinas, it is worth to mention that traces of the 'genuine paradox' recalled by John Paul II can be found also in the teachings of this Doctor of the Church. However, Thomas Aquinas sees it rather in the context of a human being itself, analysing the nature and fault of sinners. For due to his nature given by God, a man is capable of being happy and to love, as well as to receive love, whereas due to his guilt that hinders his happiness, the man takes an opposing stance to God and thus should be hated by everyone, including his father and mother. According to Doctor Angelicus, "For it is our duty to hate, in the sinner, his being a sinner, and to love in him, his being a man capable of bliss" ${ }^{23}$. This anthropological judgement can be directly translated into the matter this article seeks to address, since Thomas states unequivocally that this type of sinners whom one can expect rather to act to others' detriment than improvement must be sentenced to death under both Godly

\footnotetext{
John Paul II, Evangelium Vitae, 56. John Paul II, Evangelium Vitae, 9. John Paul II, Evangelium Vitae, 56. STh II-II q. 25, a. 6
} 
and human law. When making such a sentence, a judge is not driven by hate but love for the social good that is more valuable than an individual's life. Furthermore, "the death inflicted by the judge profits the sinner, if he be converted, unto the expiation of his crime; and, if he be not converted, it profits so as to put an end to the sin, because the sinner is thus deprived of the power to sin any more"24. This antinomic concept that assumes distinction between ontic dignity and ethical dignity ${ }^{25}$, leading to a consent to death penalty, is somewhat 'justified' by Aquinas by his assumption that death penalty can be considered compensation for the evil done, since it has expiatory value. However, this line of argument is difficult to agree with. There is serious doubt as to whether depriving a person of her fundamental good, which is life, may cause her guilt to be expiated. More likely, taking a perpetrator's life deprives him of the possibility to fix the evil done. Unless someone considers the strictest punishment compensation as part of his heroic act, although even in this case, it is not in fact a restitution of the good but only an act of redemption and reception of the sentence for a crime.

Another attempt at solving the 'genuine paradox' can be found in the writings of father Tadeusz Ślipko. The researcher proposed that a moral evaluation of death penalty (and not only) should involve the principle of 'value coordination'. The professor begins with argumentation that situates state law to take an aggressor's life as a direct continuation of an individual's right to deliver the deadly blow when protecting his own life ${ }^{26}$. Another thread of argumentation leads towards a statement that when it comes to necessary protection, as in the situation where death penalty is performed, it cannot be said that a man protecting himself do not want to kill the aggressor. According to Ślipko, the possibility to use the 'double result' principle should be negatively verified in this case. A man who is protecting himself in a situation where his life is directly threatened wishes to annihilate the aggressor as part of self-protection. This is evidenced by the nature of the act of defence that is constituted by two intents, namely, protecting one's own life and both intending death for the offender. According to the researcher, it is impossible that death of the offender be limited to an unintended yet tolerated evil ${ }^{27}$. Following the thought of Ślipko, in both situ-

24 STh II-II q. 25, a. 6, ad 2

25 The teachings of Thomas Aquinas on the dignity of a guilty (sinful) man is ambiguous. Aquinas states once that "a man who has sinned is not by nature distinct from good men; hence a public authority is requisite in order to condemn him to death for the common good." (STh II-II q. 64, a. 3, ad 3), whereas another time he claims, "By sinning man departs from the order of reason, and consequently falls away from the dignity of his manhood, [...] Hence, although it be evil in itself to kill a man so long as he preserve his dignity, yet it may be good to kill a man who has sinned, even as it is to kill a beast. For a bad man is worse than a beast, and is more harmful, as the Philosopher states" (STh, II-II q. 64, a. 2, ad 3). Therefore, we may talk here about at least some tension between dignity of a man as a personal being (bestowed by the Creator) that by nature cannot be lost and dignity in the moral sense that can be lost with unfair deeds.

26 Ślipko, Kara śmierci, 135-136.

27 Ślipko, „Kara śmierci”, 129. 
ations there is 'axiological conflict' that allows for a 'lesser evil' to take place. In the Christian ethics, moral values are objective and constant. How can one then justify the right to necessary defence and permissibility of death penalty as a continuation of the said right? Here, the concept of 'value coordination' should be put to use. It comes from a personalistic belief that moral values improve a man as a person. They form a moral order based on a certain harmonious hierarchy. This order determines the level to which a given value is attributed to the ideal of perfecting a person and creates correlations between values that allow them to become mutually complementary without falling into conflict. This is because a conflict would make values that are good in themselves and oriented at personal development depersonalizing forces. That is why there must be a mechanism owing to which in a situation of conflicting interdependences depersonalization would not take place. We are dealing with this type of conflict in a situation where a criminal perpetrates an act (acts) of blatantly unjust aggression. And this is the type of situation (and the only type of situation, according to Ślipko) to which the principle pertains, narrowing down the scope of importance of a specific objective and absolute value in a way that excludes this act from the said scope and, at the same time, makes it permissible, with the said act aside from aggression preserving its permanent characteristic of the mar of moral evil and is a morally impermissible act as such ${ }^{28}$.

Concerning the act of legal defence against an aggressor's deadly attack it should be concluded that the inviolability of the aggressor's life is somewhat 'restricted. It is not violated during the act of self-defence, although physical deprivation of the aggressor's life occurs. Such an act has no moral qualification of an "evil" deed, but that of a "neutral" one. Hence, it becomes permissible - but only within the limits of necessary defence against an aggressor. Such an approach to this problem leaves in the area of ethical evaluation additional criteria of liability for one's act, that is, fairness of the intent, exclusion of hateful vengeance, cruelty or other moral circumstances of the act ${ }^{29}$. The final part of Ślipko's argumentation consists in a transition from a situation of necessary defence as an action in the field of 'current aggression' to perceiving the state as a descendant of the right to legal defence in a situation where a given crime has already been perpetrated. According to the researcher, the right to deliver this lethal blow is transferred to the state. This is not about fixing an infringed moral order but about an individual's right to protect life being affirmed by the state.

Regardless of either agrees or polemizes with Ślipko's argumentation ${ }^{30}$, it is obvious that the proposition made by the Cracovian ethicist is nothing else but placing the problem of necessary defence and death penalty precisely in the hermeneu-

\footnotetext{
Ślipko, „Kara śmierci”, 132.

Ślipko, Kara śmierci, 133.

The most serious allegations to Ślipko's theory are centred around: (1) the thesis about the individual protecting herself against the aggressor's attack having a double intent; (2) the analogy between the situation of necessary defence and death penalty; (3) the ontic and an ethical split of the human life aspect.
} 
tic-personalistic context. It is the proper interpretation (coordination) of the relation between a value and a man as a person that becomes the key to proper interpretation of the notion of death penalty and necessary defence. Ultimately, it is the person who becomes the 'space' where values may be objectively harmonised in a way that allows the action taken by a man to have the person-creating quality.

The entirety of the analyses conducted so far leads to two basic conclusions. Firstly, that both the history of Church teachings and the personalistic hermeneutic allow one to claim that the use of death penalty as ratio ultima under specific circumstances is not in conflict with moral law and this consistency can be justified. Secondly, that not seeking this final argument due to identified importance of the personal dignity of even the greatest criminal remains an act that is by all means more worthy of a man as a person, nonetheless. Refraining from physically annihilating the aggressor, particularly when one's own life is not threatened at the time, is an act that respects to a greater degree personal dignity of the aggressor and the judge, as well as members of the entire society. This is congruent to $\mathrm{z}$ theological perspective, according to which God wants even the greatest sinner alive. This very hermeneutic, in my view, has serves as the foundation for Pope Francis's decision to change Church teachings concerning death penalty from a moderately retentionist standpoint to an abolitionist one.

\section{Continuity Hermeneutic or Discontinuity Hermeneutic?}

The recent interpretation of the Catechism of the Catholic Church that imposes adoption of abolitionism as the official stance taken by the Church on the matter of death penalty has encountered allegations about breaking off with the former centuries-old teachings of the Magisterium. Therefore, al allegation of a hermeneutic nature is made, indicating that the current interpretation of permissibility of capital punishment is in conflict with interpretations repeatedly expressed in the course of the Church history that allowed for the use of this penitentiary form in exceptional cases as ultima ratio. Taking a closer look at the public debate that emerged following the change in the Catechism one may get an impression that it is rather the hermeneutic matter that caused major 'confusion' and lack of understanding among Catholic commentators and not the very fact of prohibiting the use of death penalty alone. Therefore, it is reasonable to put forward a fundamental question, does the new interpretation of the Catechism express the continuity hermeneutic or is it already the discontinuity hermeneutic?

The Prefect of the Congregation for the Doctrine of the Faith in his Letter explaining the causes of the change in the catechism formula stated that "the new formulation of number 2267 of the Catechism expresses an authentic development of 
doctrine that is not in contradiction with the prior teachings of the Magisterium"31. At the same time, Cardinal Ladaria is well aware of a certain 'tension' between the current stance and the former one, and thus he adds that the former teachings "can be explained in the light of the primary responsibility of the public authority to protect the common good in a social context in which the penal sanctions were understood differently, and had developed in an environment in which it was more difficult to guarantee that the criminal could not repeat his crime" ${ }^{\prime 32}$. The thing that has changed in the Prefect's view, "the understanding of the inadmissibility of the death penalty grew in the light of the Gospel. The Gospel, in fact, helps to understand better the order of creation that the Son of God assumed, purified, and brought to fulfillment. It also invites us to the mercy and patience of the Lord that gives to each person the time to convert oneself" ${ }^{\prime 3}$.

When explaining the change in the Catechism formula in the key of the continuity hermeneutic, the Prefect of the Congregation for the Doctrine of the Faith refers to the teachings of the three previous popes, namely, John Paul II, Benedict XVI and Francis. Here, it should be noted that the most fundamental document used for explaining the necessity to change the teachings is the encyclical Evangelium vitae ${ }^{34}$. This gives rise to two doubts of hermeneutic nature. Firstly, there is a question why does the Prefect refer solely to the last three popes disregarding previous teachings of the Magisterium in his analyses, including councils that allowed for a conditional application of death penalty? Secondly, how to explain the fact that John Paul II himself, the author of Evangelium vitae Cardinal Ladaria refers to, did not decide to change the stance on this matter?

However, the above objections cannot obscure the fact that the teachings of John Paul II already were very clearly oriented towards abolitionism. When analysing Evangelium vitae one may put forwards a thesis that John Paul II somewhat returned to the stance of some Church Fathers from before the Edict of Milan of 313. In his teachings a certain tension appears, a kind of duality. When pondering on both the necessity to protect the common good and order, as well as in alienable dignity of the criminal, the Pope ultimately supports the state's right to use capital punishment. Nonetheless, he repeatedly makes it clear that death penalty is unacceptable in the perspective of faith, hope and Christian love. For the 'paradoxical love of God' when He punishes Cain, does not take his life, because "Not even a murderer loses his personal dignity, and God himself pledges to guarantee this"35. In turn, hope is marked by "a new sensitivity ever more opposed to war as an instrument for the resolution of conflicts between peoples, and increasingly oriented to finding effective but 'non-vi-

\footnotetext{
Congregation for the Doctrine of the Faith, Ladaria L.F., Letter to the Bishops, 8. Congregation for the Doctrine of the Faith, Ladaria L.F., Letter to the Bishops, 8. Congregation for the Doctrine of the Faith, Ladaria L.F., Letter to the Bishops, 9. Congregation for the Doctrine of the Faith, Ladaria L.F., Letter to the Bishops, 3. John Paul II, Evangelium Vitae, 9.
} 
olent' means to counter the armed aggressor. In the same perspective there is evidence of a growing public opposition to the death penalty, even when such a penalty is seen as a kind of 'legitimate defence' on the part of society. Modern society in fact has the means of effectively suppressing crime by rendering criminals harmless without definitively denying them the chance to reform ${ }^{\prime 36}$. In this view, Francis's decision to change the interpretation of the Catechism may be perceived in the categories of the continuity hermeneutic. After all, it includes the clear statement that considering death penalty impermissible stems directly from the light of the Gospel. However, as far as in Evangelium vitae despite the 'genuine paradox' John Paul II maintained the right to use capital punishment, Francis decided to change that.

The authentic continuity hermeneutic or the 'hermeneutic of reform' to use the words of Benedict XVI must express continuity over centuries ${ }^{37}$. The doctrinal continuity stems from the continuity of the only subject-Church that Jesus Christ left. Therefore, a change in the teachings one could refer to as the "hermeneutic of rupture and breaking off with the past" could lead to a schism in the Church into the Church 'before' and the Church 'after', which in fact would mean negating the continuity of its history. Nonetheless, in this context one should notice that the new wording of no. 2267 refers to the previous teachings of the Church stating that "Recourse to the death penalty on the part of legitimate authority, following a fair trial, was long considered an appropriate response to the gravity of certain crimes and an acceptable, albeit extreme, means of safeguarding the common good" ${ }^{\prime 3}$. This does not pertain to negating permissibility of capital punishment in the past but to a shift in the future approach. This shift, which is a novelty, comes from three fundamental premises, namely, (1) the increasingly more consolidated awareness that a person never loses her dignity; (2) the new understanding of the role of criminal sanctions; (3) the introduction of new ways for limiting the freedom that by ensuring protection of citizens allow the sentenced person to redeem him- or herself from guilt at the same time.

Similar premises encouraged the Church to a certain correction (actualisation, specifically) of teachings when it comes to the so-called 'just war', restricting the possibility to use military force to cases of defensive war or intervention to protect a country that was maliciously invaded by an aggressor ${ }^{39}$. The Church has changed its teachings, for instance, in the area of heliocentrism or the literal understanding of the ontogenesis in line with the word of the Book of Genesis. In each of these cases, it was due to the new social awareness and scientific data that the stance of the Church was corrected (actualized).

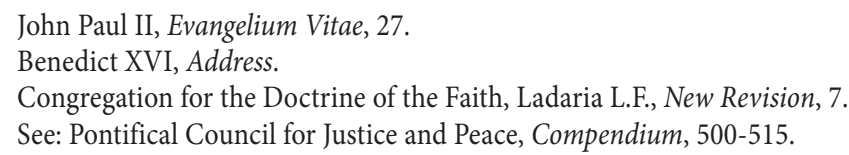


Returning to the new interpretation of permissibility of death penalty one has to admit that it corresponds to Thomas's thesis about the necessity to choose an action adequate for a given threat. It should be recalled that when Aquinas considers the possibility to kill an attacker in an act of protection, he states that such a blow is permissible conditionally in a situation where it is an action adequate to the threat. It is only when a man's life is at risk that he is allowed to deliver a lethal blow to protect himself, since it constitutes an unintended result, because the intent and the will was just to protect life ${ }^{40}$. Applying the same logic to the matter of death penalty, whenever a criminal can be effectively isolated from society, killing him as an unintended but necessary result is no longer relevant. Therefore, in this case, a shift in the external conditions (the efficiency of penitentiary bodies) has a great impact on permissibility of the use of capital punishment.

The above-listed arguments justifying the new Catechism interpretation as maintained in the hermeneutic continuity in relation to the traditional teachings of the Church seem stronger than the ones according to which it should be classified as the discontinuity hermeneutic. Nonetheless, one should bear in mind that both former and present teachings of the Church on this subject are ordinary teachings (magisterium ordinarium). This sort of teaching calls for obedience of faith, yet it is not ceremonious teaching (ex cathedra) that is entitled to infallibility and definitiveness. Therefore, further development of argumentation both of abolitionist and retentionist nature is possible.

\section{Conclusion}

The above-conducted analyses convince that the issue of permissibility of the application of death penalty is a hermeneutic problem. Its horizon stretches between the duty to protect the common good and social order, that is, the social life space and an individual's actions and the necessity to identify and respect personal dignity of every man, also that of a criminal. The willingness to compensate for the obligation to protect society and each human life without exceptions leads to a certain hermeneutic tension that is well reflected by John Paul II, who referred to the 'genuine paradox'. In the history of claims made by theologists and the Magisterium concerning permissibility of death penalty one may find various ways to overcome the sad paradox. For many centuries, the 'interpretative account' was dominant, allowing for the use of capital punishment in specific cases, and thus in fact putting the common good over the good of an individual. At present, however, due to the interpretative charge' contained in the abolitionist argumentation, supported by new possibilities

$40 \quad$ STh II-II q. 64, a. 7. 
in the penitentiary field, the Church expressed its stance for the use of death penalty. Nonetheless, this voice does not result in a lesser importance of protecting the common good and social order. On the contrary, on the present historical stage abolitionism reconciles the necessity for protecting a community against potential threats on the part of a criminal with the respect for inalienable dignity, even that of a morally unfair life. Thus, it is refraining from the use of capital punishment, even in cases where the retentionist argumentation is considered justifiable, that constitutes the model of handling criminals that is closest to Christianity.

To conclude, it is worth to take a look once again at the issue of capital punishment in a somewhat broader perspective. The prohibition to proceed and perform death penalty is a significant step in propagation of the 'civilisation of life' and correct the logic of the 'civilisation of death'. Aside from showing the holiness of life from contraception to natural death, aside from promoting the logic of peace, abolitionism states as well, to use the words of John Paul II, another gesture that provides "the bases of the civilisation of love and life" ${ }^{\text {"11 }}$, without which the existence of people and society loses its most human meaning.

\section{Bibliography}

Augustine of Hippo, The Works of Aurelius Augustine, Bishop of Hippo. I. The City of God (trans. M. Dods) (Edinburgh: T \& T Clark 1913).

Benedict XVI, Address of His Holiness Benedict XVI to the Roman Curia Offering Them His Christmas Greetings (Vatican: Libreria Editrice Vaticana 2005) (http://w2.vatican.va/content/ benedict-xvi/en/speeches/2005/december/documents/hf_ben_xvi_spe_20051222_roman-curia.html [access: 20.12.2019]).

Benedict XVI, Postsynodal Apostolic Exhortation "Africa munus" (Vatican: Libreria Editrice Vaticana 2011) (http://w2.vatican.va/content/benedict-xvi/en/apost_exhortations/ documents/hf_ben-xvi_exh_20111119_africae-munus.html [access: 20.12.2019]).

Catechism of the Catholic Church (Vatican: Libreria Editrice Vaticana 1992).

Catechism of the Catholic Church, 2nd ed. (Vatican: Libreria Editrice Vaticana 1998) (http:// www.vatican.va/archive/ENG0015/_INDEX.HTM [access: 20.12.2019) (= CCC).

Clement of Alexandria, Stromateis. Books 1-3 (trans. J. Ferguson) (The Fathers of the Church 85; Washington D.C.: Catholic University of America Press 1991).

Congregation for the Doctrine of the Faith, Ladaria L.F., "New revision of number 2267 of the Catechism of the Catholic Church on the death penalty" (Rescriptum ex Audentia SS.MI)", L'Osservatore Romano (3 August (2018) 7. https://press.vatican.va/content/salastampa/en/ bollettino/pubblico/2018/08/02/180802a.html

Congregation for the Doctrine of the Faith, Ladaria L.F., Letter to the Bishops regarding the new revision of number 2267 of the Catechism of the Catholic Church on the death penalty,

41 John Paul II, Evangelium Vitae, 27. 
from the Congregation for the Doctrine of the Faith (Vatican: Libreria Editrice Vaticana 2018). Available at:( https://press.vatican.va/content/salastampa/en/bollettino/pubblico/2018/08/02/180802b.html [access: 20.12.2019]).

Francis, "Address to Participants in the Meeting organized by the Pontifical Council for the Promotion of the New Evangelization", L'Osservatore Romano 13 October (2017) 5.

Francis, "Letter to the President of the International Commission Against the Death Penalty", L'Osservatore Romano 20-21 March (2015) 7.

John Paul II, Encyclical Letter Evangelium Vitae (Vatican: Libreria Editrice Vaticana 1995).

Pontifical Council for Justice and Peace, Compendium of the Social Doctrine of the Church

(Vatican: Libreria Editrice Vaticana 2004) (http://www.vatican.va/roman_curia/pontifical_councils/justpeace/documents/rc_pc_justpeace_doc_20060526_compendio-dott-soc_en.html [access: 20.12.2019]).

Ślipko T., „Kara śmierci z filozoficznego punktu widzenia”, Resovia Sacra 13 (2006) 125-136.

Ślipko, T., Kara śmierci z teologicznego i filozoficznego punktu widzenia (Kraków: WAM 2000).

Thomas Aquinas, Summa Theologica (trans. by Fathers of the English Dominican Province) (London: Thomas Baker 1947) (= STh).

Thompson, P.M., "Augustine and the Death Pentality: Justice as the Balance of Mercy and Judgment," Augustinian Studies 40/2 (2009) 181-203.

Washburn, Ch. D., "The New Natural Lawyers, Contraception, Capital Punishment, and the Infallibility of the Ordinary Magisterium," Logos 22 (2019) 19-50. 